\title{
Pengaruh Financing To Deposit Ratio (FDR), Risiko Pembiayaan, Kecukupan Modal, Dana Pihak Ketiga, Suku Bunga, dan Inflasi Terhadap Profitabilitas pada Bank Umum Syariah di Indonesia
}

\author{
Kamelia $^{1}$, Eliyanora ${ }^{2}$, dan Gustati ${ }^{3}$ \\ ${ }^{1}$ Program Studi Diploma IV Akuntansi Jurusan Akuntansi, Politeknik Negeri Padang \\ Email: kameliaamelka@gmail.com \\ 2 Program Studi Diploma IV Akuntansi Jurusan Akuntansi, Politeknik Negeri Padang \\ Email: eliyanora@yahoo.com \\ 3 Program Studi Diploma IV Akuntansi Jurusan Akuntansi, Politeknik Negeri Padang \\ Email: gustati1602@yahoo.com
}

\begin{abstract}
This study aims to examine the effect of financing to deposit ratio (FDR), financing risk, capital adequacy, third-party funds, interest rates, and inflation on profitability of Islamic Commercial Banks in Indonesia. The independent variables used in this study are financing to deposit ratio (FDR), financing risk, capital adequacy, third-party funds, interest rates, and inflation. The dependent variable is the profitability that measured using the return on assets (ROA). The study population are 13 Islamic Commercial Banks that registered in the Financial Services Authorities and Indonesian Bank during 2013-2017. Determination of sample was made by applying purposive sampling method and obtaining the sample of 9 Islamic Commercial Banks. Analysis of data used is multiple regression with the help of SPSS version 20. The results showed that financing risk had a significant effect on profitability, while financing to deposit ratio (FDR), capital adequacy, third-party funds, interest rates, and inflation had no significant effect on profitability.
\end{abstract}

Keywords: Profitability, Financing To Deposit Ratio (FDR), Risk of Financi Party Funds, Interest Rates, Inflation

ng, Capital Adequacy, Third

ABSTRAK

Penelitian ini bertujuan untuk menguji pengaruh financing to deposit ratio (FDR), risiko pembiayaan, kecukupan modal, dana pihak ketiga, suku bunga, dan inflasi terhadap profitabilitas pada Bank Umum Syariah di Indonesia. Variabel independen yang digunakan dalam penelitian ini adalah financing to deposit ratio (FDR), risiko pembiayaan, kecukupan modal, dana pihak ketiga, suku bunga, dan inflasi. Variabel dependen dalam penelitian ini adalah profitabilitas yang diukur menggunakan ukuran return on asset (ROA). Populasi penelitian adalah 13 Bank Umum Syariah yang terdaftar di Otoritas Jasa Keuangan dan Bank Indonesia selama tahun 2013-2017. Penentuan sampel pada penelitian menggunakan purposive sampling dan memperoleh sampel sebanyak 9 Bank Umum Syariah. Analisis data yang digunakan adalah regresi berganda dengan bantuan SPSS versi 20. Hasil penelitian ini menyatakan bahwa risiko pembiayaan berpengaruh signifikan terhadap profitabilitas, sedangkan financing to deposit ratio (FDR), kecukupan modal, dana pihak ketiga, suku bunga, dan inflasi tidak berpengaruh signifikan terhadap profitabilitas.

Kata kunci: Profitabilitas, Financing To Deposit Ratio (FDR), Risiko Pembiayaan, Kecukupan Modal, Dana Pihak Ketiga, Suku Bunga, Inflasi 


\section{PENDAHULUAN}

Sebagian besar masyarakat Indonesia beragama Islam. Sehingga, konsep Islam sudah semakin berkembang di lingkungan masyarakat hingga saat ini. Misalnya saja dalam bidang pendidikan, semakin banyaknya lembaga-lembaga pendidikan berbasis Islam. Dalam hal makanan juga terjadi perubahan, dan masyarakat sudah semakin peduli dengan makanan yang halal yang telah bersertifikasi. Begitu juga dengan lembaga keuangan, sudah semakin banyak lembaga keuangan yang berdasarkan konsep Islam. Salah satu yang paling pesat perkembangannya adalah lembaga perbankan, yang kemudian diperkuat dengan adanya UU Republik Indonesia Nomor 21 tahun 2008 mengenai perbankan syariah.

Wibowo dan Syaichu (2013) menyatakan perbankan syariah telah membuktikan dirinya sebagai suatu sistem yang tangguh dan mampu bertahan melalui krisis ekonomi pada tahun 1998. Hal ini menunjukkan bahwa sistem perbankan syariah memiliki suatu keunggulan. Dimana pada saat itu bank konvensional mengalami negative spread, namun tidak demikian dengan perbankan syariah. Belajar dari peristiwa tersebut, perbankan syariah mulai berkembang di Indonesia. Perkembangan mengenai perbankan syariah tersebut dapat terlihat pada tabel 1.1 di bawah ini:

Tabel 1. Perkembangan Bank Syariah di Indonesia

\begin{tabular}{|l|r|r|r|r|r|}
\hline \multicolumn{1}{|c|}{ Kelompok Bank } & \multicolumn{1}{c|}{$\mathbf{2 0 1 3}$} & \multicolumn{1}{c|}{$\mathbf{2 0 1 4}$} & \multicolumn{1}{c|}{$\mathbf{2 0 1 5}$} & \multicolumn{1}{c|}{$\mathbf{2 0 1 6}$} & \multicolumn{1}{c|}{$\mathbf{2 0 1 7}$} \\
\hline Bank Umum Syariah (Jumlah Bank) & 11 & 12 & 12 & 13 & 13 \\
\hline Jumlah Kantor BUS & 1.998 & 2.151 & 1.990 & 1.869 & 1.825 \\
\hline Layanan Syariah Bank (LSB) & 2.092 & 2.160 & 2.175 & 2.655 & 3.026 \\
\hline Unit Usaha Syariah & 23 & 22 & 22 & 21 & 21 \\
\hline Jumlah Kantor UUS & 590 & 320 & 311 & 332 & 344 \\
\hline Layanan Syariah (LS) & 1.267 & 1.787 & 2.009 & 2.567 & 2.624 \\
\hline BPRS & 163 & 163 & 163 & 166 & 167 \\
\hline Layanan Syariah (LS) & 402 & 439 & 446 & 453 & 441 \\
\hline Jumlah Kantor BUS, UUS \& BPRS & 2.990 & 2.910 & 2.747 & 2.654 & 2.610 \\
\hline
\end{tabular}

Sumber: Laporan Perkembangan Keuangan Syariah Indonesia (2017)

Berdasarkan Laporan Perkembangan Keuangan Syariah Indonesia (2017) diketahui bahwa komposisi sumber dana perbankan syariah (tidak termasuk modal) pada tahun 2017 secara umum didominasi oleh Dana Pihak Ketiga (DPK) yaitu mencapai 85,78\% dari total sumber dana perbankan syariah. Peningkatan DPK yang masih tinggi menunjukkan tingkat kepercayaan nasabah yang semakin baik terhadap perbankan syariah. Sedangkan secara keseluruhan komposisi aset, Pembiayaan yang Disalurkan (PYD), dan Dana Pihak Ketiga (DPK) sampai dengan tahun 2017 didominasi oleh BUS dengan persentase 67,15\%., 64,67\% dan 49,39\% dari total keseluruhan perbankan syariah.

Sebagai lembaga yang bertugas untuk menetapkan dan melaksanakan kebijakan moneter, Bank Indonesia (BI) mempunyai peran dalam rangka mengendalikan jumlah uang yang beredar untuk mendorong perekonomian nasional. Menurut Bank Indonesia (2013) dijelaskan bahwa Bank Indonesia akan memperhatikan faktor-faktor terkait dengan BI rate dan inflasi dalam hubungunnya dengan perekonomian. Menurut Wibowo dan Syaichu (2013) jika inflasi meningkat 
merupakan suatu signal negatif karena hal itu akan berdampak dengan profitabilitas sebuah perusahaan.

Mahmudah dan Harjanti (2016) menyatakan, suatu perbankan syariah memiliki peranan dan fungsi yang begitu penting. Oleh karena itu perbankan syariah perlu memperbaiki kinerjanya untuk menciptakan perbankan syariah yang efisien dan sehat. Untuk pengukuran profitabilitas bisa menggunakan Return On Asset (ROA). Pengukuran ini dapat memperlihatkan kinerja manajemen dalam menghasilkan keuntungan dari pengelolaan atas aset yang dimilikinya. Kemudian, dalam informasi Laporan Perkembangan Keuangan Syariah Indonesia (2017) menunjukkan bahwa dari tahun 2013 sampai tahun 2017 Return On Assset (ROA) Bank Umum Syariah (BUS), Unit Usaha Syariah (UUS) dan Bank Pembiayaan Rakyat Syariah (BPRS) juga mengalami penurunan dari tahun 2013 yang terdapat pada gambar 1.1 di bawah ini:

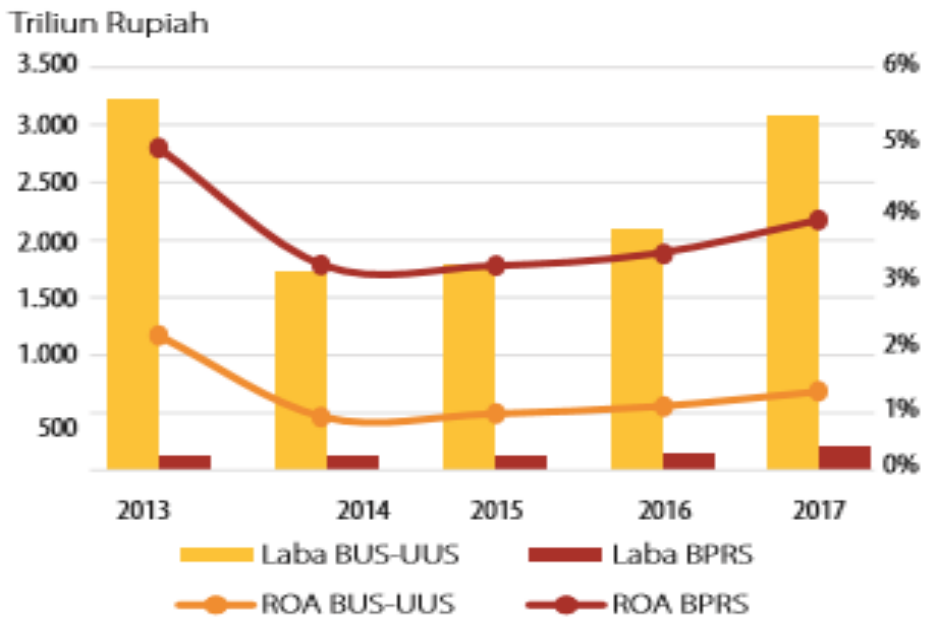

Gambar 1. ROA BUS, UUS dan BPRS tahun 2013-2017, Sumber: LPKS (2017)

Melihat berbagai permasalahan dalam dunia perbankan, sebenarnya sudah ada peneliti yang membahas mengenai profitabilitas perbankan dan faktor-faktor yang bisa mempengaruhinya. Faktor-faktor tersebut tidak hanya berasal dari internal perusahaan, tetapi jaga berasal dari eksternal. Seperti penelitian yang dilakukan oleh penelitian terdahulu dengan beberapa variabel penelitian yaitu Capital Adequacy Ratio (CAR), Financing to Deposit Ratio (FDR), Non Performing Financing (NPF), BOPO, dan Dana Pihak Ketiga (DPK) terhadap variabel dependen yaitu profitabilitas. Wibowo dan Syaichu (2013) serta Kalengkongan (2013) menggunakan beberapa variabel faktor eksternal seperti tingkat suku bunga dan inflasi dan bagaimana faktor tersebut mempengaruhi profitabilitas bank. Berdasarkan hasil penelitian sebelumnya, dari penggunaan variabel tersebut adanya perbedaan hasil yaitu ada yang menyatakan variabel tersebut berpengaruh, namun ada juga yang menyatakan tidak berpengaruh. Oleh karena itu penulis ingin meneliti lebih lanjut mengenai variabel yang mempengaruhi tingkat profitabilitas yang diukur dengan Return On Asset (ROA).

\section{METODE PENELITIAN}

\section{Desain Penelitian}

Sugiyono (2017) penelitian ini merupakan penelitian kuantitatif yang berbentuk asosiatif, yaitu sebuah penelitian yang mengungkap suatu pengaruh dan bagaimana 
hubungan antar variabel dengan menggunakan data berupa angka-angka. Penulis mengumpulkan data terkait dengan faktor pendukung yang akan digunakan dalam penelitian terkait dengan variabel yang diteliti. Kemudian, data tersebut akan dianalisis dengan menggunakan alat analisis yang sesuai dengan variabel-variabel dalam penelitian.

\section{Jenis Dan Sumber Data}

Dalam penelitian ini data yang digunakan merupakan data sekunder, yaitu berupa laporan keuangan publikasi tahunan masing-masing bank. Data tersebut diperoleh melalui penelusuran melalui website masing-masing bank yang diteliti selama lima tahun berturut-turut dari periode tahun 2013 sampai tahun 2017 dan data mengenai inflasi dan suku bunga diperoleh melalui website Badan Pusat Statistik (BPS).

\section{Populasi dan Sampel}

Populasi dalam penelitian ini adalah seluruh Bank Umum Syariah yang terdapat pada Otoritas Jasa Keuangan (OJK) dan Bank Indonesia (BI) pada tahun 2013 sampai tahun 2017. Teknik sampel yang penulis gunakan dalam penelitian ini yaitu metode purposive sampling. Dalam metode ini pengambilan sampel didasarkan pada beberapa pertimbangan atau kriteria-kriteria yang telah ditetapkan. Kriteria pemilihan sampel yang dipertimbangkan dan ditentukan oleh penulis yaitu: (1) Bank umum syariah yang ada di Indonesia dan beroperasi tahun 2013 sampai tahun 2017. (2) Tersedia laporan keuangan tahunan dan terdapat data mengenai variabel yang diteliti selama jangka waktu penelitian yaitu dari tahun 2013 sampai dengan tahun 2017.

\section{Definisi Operasional dan Pengukuran Variabel}

Dalam penelitian ini, variabel yang digunakan dalam penelitian ini adalah:

\section{a. Variabel Dependen}

Profitabilitas bank memperlihatkan bagaimana kemampuan bank tersebut memperoleh keuntungan atas aset yang telah digunakan dalam menjalankan bisnisnya. Dalam penelitian ini pengukuran profitabilitas yang digunakan adalah Return On Asset (ROA).

$\mathrm{ROA}=\frac{\text { Laba Sebelum Pajak }}{\text { Total Aset }} \times \quad 100 \%$

\section{b. Variabel Independen}

1) Financing To Deposit Ratio (FDR)

Yusuf dan Mahriana (2016) menyatakan Financing to Deposit Ratio (FDR) adalah sebuah rasio untuk mengukur komposisi jumlah pembiayaan yang diberikan dibandingkan dengan jumlah dana dari masyarakat yang digunakan. Rasio ini dihitung dengan cara membandingkan antara total pembiayaan dan dana pihak ketiga. Rumus untuk menghitung FDR ini adalah:

$$
\mathrm{FDR}=\frac{\text { Total Pembiayaan }}{\mathrm{DPK}} \times \quad 100 \%
$$


2) Risiko Pembiayaan

Non Performing Financing (NPF) bertujuan untuk mengukur tingkat permasalahan pembiayaan yang dihadapi oleh bank. Variabel tingkat risiko pembiayaan diukur dengan Non Performing Financing (NPF) yang terdapat pada laporan tahunan. NPF diukur dengan membandingkan pembiayaan bermasalah dengan total pembiayaan, yaitu dihitung dengan rumus:

$$
\mathrm{NPF}=\frac{\text { Jumlah Pembiayaan bermasalah }}{\text { Total Pembiayaan }} \times \quad 100 \%
$$

3) Kecukupan Modal

Muhamad (2014) menjelaskan kecukupan modal merupakan hal penting dalam bisnis perbankan. Bank yang sehat mempunyai suatu tingkat kecukupan modal yang baik. Sebab kecukupan modal menunjukkan keadaannya yang dinyatakan dengan suatu rasio tertentu yang disebut dengan rasio kecukupan modal. Rasio kecukupan modal suatu bank dapat diukur dengan menggunakan Capital Adequency Ratio (CAR).

$$
\mathrm{CAR}=\frac{\text { Modal Sendiri }}{\mathrm{ATMR}} \times 100 \%
$$

4) Dana Pihak Ketiga

Dana Pihak Ketiga (DPK) adalah dana bank yang bersumber dari pihak luar, yaitu merupakan dana yang diperoleh dari tabungan, giro dan deposito. Pengukuran dana pihak ketiga dilakukan dengan menjumlahkan seluruh dana pihak ketiga yang didapatkan melalui laporan tahunan masing-masing bank yaitu berupa tabungan, giro dan deposito. Selanjutnya data yang digunakan untuk penelitian ini adalah hasil logaritma natural dari total DPK tersebut.

DPK= Ln Total DPK

5) Suku Bunga

Menurut Bank Indonesia (2013), BI rate merupakan suatu hal yang memperlihatkan bagaimana Bank Indonesia mengambil sikap atau kebijakan dalam mengambil tindakan dalam kebijakan moneter tersebut. Dalam penelitian ini suku bunga yang dipakai merupakan BI rate. Dimana BI rate yang dipakai merupakan BI rate yang telah Bank Indonesia (BI) tetapkan.

6) Inflasi

Bank Indonesia (2013), menyatakan bahwa inflasi merupakan suatu hal yang diartikan sebagai harga-harga yang meningkat secara terus menerus dan umum. Data inflasi yang penulis gunakan bersumber dari data inflasi yang Bank Indonesia (BI) telah tetapkan.

\section{Metode Pengumpulan Data}

Penulis menggunakan metode pengumpulan data metode studi dokumentasi, yaitu dengan cara mendapatkan data berupa laporan tahunan yang dikeluarkan oleh 
masing-masing bank yang terdapat pada Otoritas Jasa Keuangan dan Bank Indonesia pada periode 2013-2017. Pengumpulan data dilakukan dengan melihat data-data yang diperlukan, mencatat, dan menganalisis laporan tahunan pada periode 20132017.

\section{Metode Analisis}

Analisis regresi linier berganda merupakan analisis yang digunakan, dimana alat bantu statistik SPSS versi 20. Analisis data terdiri dari statistik deskriptif, uji asumsi klasik, dan uji hipotesis (uji t, uji F, dan uji Koefisien Adjusted R²). Dari penetapan kriteria pemilihan sampel berdasarkan metode purposive sampling tersebut, terdapat 9 Bank Umum Syariah yang terpilih dari 13 Bank Umum Syariah yang ada. Jadi, dari 9 bank yang terpilih akan ada 45 data yang digunakan dalam masing-masing variabel yang dipakai dalam penelitian ini.

Sugiyono (2017) menyatakan terdapat perbedaan yang mendasar antara analisis korelasi dan regresi. Analisis korelasi digunakan untuk mencari arah dan kuatnya hubungan antara dua variabel atau lebih, sedangkan analisis regresi digunakan untuk memprediksikan seberapa jauh perubahan nilai variabel dependen bila nilai variabel independen dimanipulasi/dirubah-rubah atau dinaik turunkan. Manfaat dari hasil analisis regresi adalah untuk membuat keputusan apakah naik dan menurunnya variabel dependen dapat dilakukan melalui peningkatan variabel independen atau tidak. Data analisis dengan anlisis regresi linear berganda pada tingkat signifikansi 2,5\%. Sebelum melakukan analisis linear berganda, terlebih dahulu dilakukan uji asumsi klasik agar hasil tidak bias. Model analisis regresi linear berganda yang dilakukan adalah sebagai berikut:

$$
\mathrm{ROA}_{i t}=\alpha 0+\beta 1 \mathrm{FDR}_{\mathrm{it}}+\beta 2 \mathrm{NPF}_{\mathrm{it}}+\beta 3 \mathrm{CAR}_{\mathrm{it}}+\beta 4 \mathrm{DPK}_{\mathrm{it}}+\beta 5 \mathrm{Br}_{\mathrm{it}}+\beta 6 \mathrm{Inf}+\varepsilon
$$

$\begin{array}{ll}\text { Keterangan: } & \\ \text { ROA } & \text { : Profitabilitas } \\ \alpha 0 & \text { : Konstanta } \\ \text { FDR } & \text { : Financing to Deposit Ratio } \\ \text { NPF } & \text { : Risiko Pembiayaan } \\ \text { CAR } & \text { : Kecukupan Modal } \\ \text { DPK } & \text { : Dana Pihak Ketiga } \\ \text { BI rate } & \text { : Suku Bunga } \\ \text { Inf } & \text { : Inflasi } \\ \beta 1 \ldots \beta 6 & : \text { Koefisien X1...X6 } \\ \varepsilon & : \text { Error }\end{array}$

\section{HASIL DAN PEMBAHASAN}

Data penelitian diolah menggunakan analisis regresi linier berganda dengan aplilkasi SPSS versi 20. Sebelum melakukan regresi linier berganda, langkah yang terlebih dahulu dilakukan adalah melalui analisis statistik deskriptif dan uji asumsi klasik untuk melihat apakah model regresi layak digunakan atau tidak. 


\section{Analisis Statistik Deskriptif}

Analisis ini digunakan untuk membandingkan nilai minimum, nilai maksimum, ratarata sampel dan standar deviasi.

Tabel 2. Hasil Uji Statistik Deskriptif

\begin{tabular}{|l|r|r|r|r|r|}
\hline & \multicolumn{1}{|c|}{$\mathrm{N}$} & \multicolumn{1}{c|}{ Minimum } & \multicolumn{1}{c|}{ Maximum } & \multicolumn{1}{c|}{ Mean } & \multicolumn{1}{c|}{ Std. Deviation } \\
\hline ROA & 45 &,- 2013 &, 0550 &,- 002000 &, 0400538 \\
FDR & 45 &, 7187 & 1,5777 &, 934600 &, 1677081 \\
NPF & 45 &, 0000 &, 0493 &, 026880 &, 0168687 \\
CAR & 45 &, 1110 &, 7583 &, 220873 &, 1402003 \\
DPK & 45 & 27,0539 & 31,9865 & 29,651458 & 1,4977138 \\
Blrate & 45 &, 0456 &, 0754 &, 064200 &, 0111738 \\
Inflasi & 45 &, 0302 &, 0838 &, 053440 &, 0250579 \\
Valid N (listwise) & 45 & & & & \\
\hline
\end{tabular}

Sumber: Data Diolah (2018)

Berdasarkan tabel 2 di atas maka dapat diketahui beberapa ukuran deskriptif dari setiap variabel penelitian. ROA (Y), terdapat 45 observasi yang dilakukan pada variabel dimana nilai terkecil $-0,2013$, nilai terbesar 0,0550 . Rata-rata kerugian yang ditanggung oleh aset pada Bank Umum Syariah -0,002000 dengan standar deviasi 0,0400538. FDR (X1) terdapat 45 observasi yang dilakukan pada variabel dimana nilai terkecil 0,7187 dan nilai terbesar 1,5777 sedangkan rata-rata FDR 0,934600 dengan standar deviasi 0,1677081 . NPF (X2) terdapat 45 observasi yang dilakukan pada variabel dimana nilai terkecil 0,0000 dan nilai terbesar 0,0493. Rata-rata NPF bernilai 0,026880 dengan standar deviasi 0,0168687. CAR (X3) terdapat 45 observasi yang dilakukan pada variabel dimana nilai terkecil 0,1110 dan nilai terbesar 0,7583. Rata-rata CAR bernilai 0,220873 dengan standar deviasi 0,1402003. DPK (X4) terdapat 45 observasi yang dilakukan pada variabel dimana nilai terkecil 27,0539 dan nilai terbesar 31,9865. Rata-rata DPK bernilai 29,651458 dengan standar deviasi 1,4977138 . BI rate (X5) terdapat 45 observasi yang dilakukan pada variabel dimana nilai terkecil 0,0456 dan nilai terbesar 0,0754. Rata-rata BI rate bernilai 0,064200 dengan standar deviasi 0,0111738. Inflasi (X6) terdapat 45 observasi yang dilakukan pada variabel dimana nilai terkecil 0,0302 dan nilai terbesar 0,0838. Rata-rata inflasi bernilai 0,053440 dengan standar deviasi 0,0250579.

\section{Uji Asumsi Klasik}

\section{a. Uji Normalitas}

Ghozali (2009) Uji normalitas bertujuan untuk menguji pendistribusian data dalam model regresi variabel independen dan variabel dependen atau keduanya terdistribusikan secara normal atau tidak. Uji normalitas dilakukan dengan menggunakan P-Plot Test. Dimana data dikatakan normal apabila data tersebut menyebar disekitar garis diagonal dan data mengikuti arah diagonalnya. 


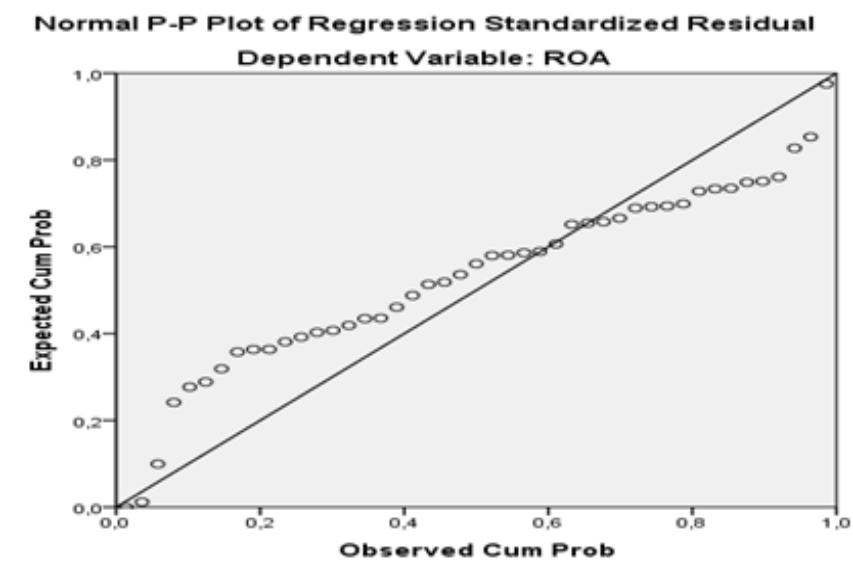

Gambar 3. Hasil Uji P-Plot Test, Sumber: Data Diolah (2018)

Dilihat dari grafik normalitas pada gambar 2 di atas terlihat bahwa titik-titik menyebar di sekitar garis diagonal dan penyebarannya mengikuti arah garis diagonal (mengikuti pada wilayah garis linear), hal ini menunujukkan bahwa model regresi layak dipakai karena memenuhi asumsi normalitas.

Hasil ini juga diperkuat oleh uji normalitas menggunakan One-Sampel Kolmogorov-Smirnov Test. Berikut hasil uji normalitas menggunakan OneSampel Kolmogorov-Smirnov Test:

\section{Tabel 3. Hasil uji One-Sampel Kolmogorov Smirnov}

\begin{tabular}{|c|c|c|}
\hline & & $\begin{array}{l}\text { Unstandardized } \\
\text { Residual }\end{array}$ \\
\hline $\mathrm{N}$ & & 45 \\
\hline 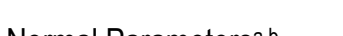 & Mean & 0E-7 \\
\hline Normal rarameters & Std. Deviation & ,03255839 \\
\hline & Absolute & ,192 \\
\hline Most Extreme Differences & Positive & ,156 \\
\hline & Negative &,- 192 \\
\hline Kolmogorov-Smirnov Z & & 1,287 \\
\hline Asymp. Sig. (2-tailed) & &, 073 \\
\hline
\end{tabular}

a. Test distribution is Normal.

b. Calculated from data.

Sumber: Data Diolah (2018)

Dari tabel 4.4 dapat dilihat nilai signifikansinya adalah sebesar 0,073 yang menunjukkan bahwa nilai signifikansinya lebih besar dari 0,05 , sehingga dapat disimpulkan bahwa data terdistribusi secara normal, sehingga model penelitian ini telah memenuhi kriteria uji asumsi klasik normalitas.

\section{b. Uji Multikolinearitas}

Menurut Ghozali (2009) untuk mendeteksi adanya multikolinearitas, dapat dilakukan dengan melihat nilai tolerance dan variance inflation factor (VIF) serta besar korelasi antara variabel independen. Model dinyatakan terbebas dari gangguan mutikolinearitas jika mempunyai nilai VIF dibawah 10 atau tolerance diatas 0,1. Adapun hasil uji mutikolinearitas dalam penelitian ini sebagai berikut:

Tabel 4. Hasil Uji Multikolinearitas

\begin{tabular}{|l|l|}
\hline Model & Collinearity Statistics \\
\hline
\end{tabular}




\begin{tabular}{|c|c|c|c|}
\hline & & Tolerance & VIF \\
\hline \multirow{7}{*}{1} & (Constant) & & \\
\hline & FDR & 464, & 2,156 \\
\hline & NPF & ,756 & 1,322 \\
\hline & CAR & ,359 & 2,788 \\
\hline & DPK & ,578 & 1,731 \\
\hline & Blrate & ,737 & 1,358 \\
\hline & Inflasi & ,725 & 1,380 \\
\hline
\end{tabular}

Sumber: Data Diolah (2018)

Berdasarkan tabel 4.5 di atas dapat diketahui bahwa hasil uji multikolinearitas menunjukkan bahwa nilai tolerance di atas 0,1 dan nilai Variance Inflation Factor (VIF) di bawah 10 untuk setiap variabel. Nilai tolerance yang dihasilkan untuk variabel FDR, NPF, CAR, DPK, BI rate, dan inflasi masing-masing adalah 0,464., 0,756., 0,359., 0,578., 0,737 dan 0,725. Sedangkan nilai VIF yang dihasilkan untuk masing-masing variabel FDR, NPF, CAR, DPK, BI rate, dan inflasi adalah 2,156., 1,322., 2,788., 1,731., 1,358 dan 1,380. Berdasarkan hasil uji multikolinearitas, data tersebut tidak terjadi multikolinearitas.

\section{c. Uji Heteroskedastisitas}

Menurut Ghozali (2009) uji heteroskedastisitas dilakukan dengan memplotkan grafik antara SRESID dan ZPRED dimana gangguan heteroskedasitas akan tampak dengan adanya pola tertentu pada grafik. Berikut hasil uji heteroskedastisitas pada model penelitian ini yang dapat dilihat pada gambar 4:

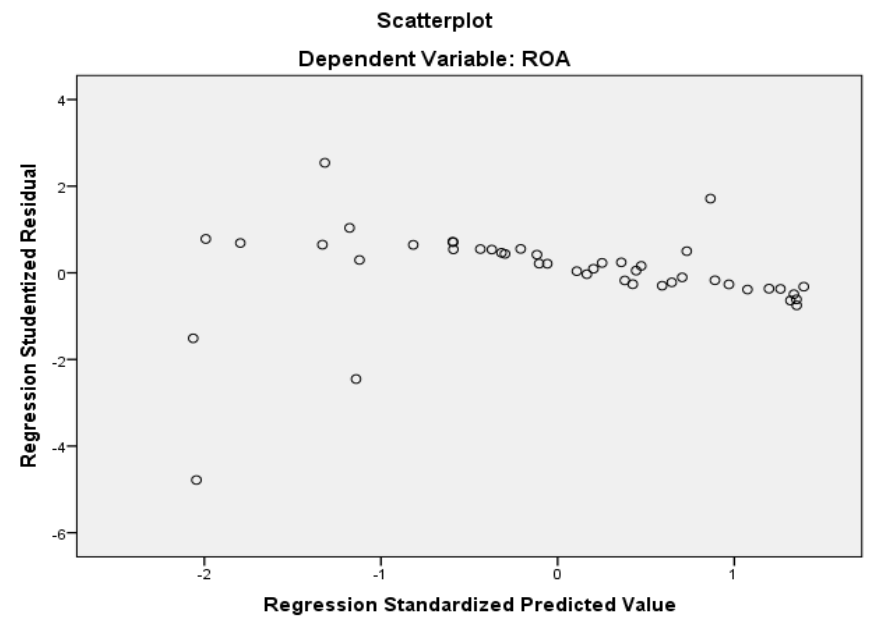

Gambar 4. Hasil Uji Heteroskedastisitas, Sumber: Data Diolah (2018)

Dari grafik scatterplots menunjukkan titik-titik telah menyebar secara acak, baik di atas dan di bawah angka nol pada sumbu Y. Dengan demikian, pada model regresi tidak terjadi heteroskidasitas.

\section{d. Uji Autokorelasi}

Menurut Ghozali (2009) uji ini bertujuan untuk memperlihatkan bagaimana hubungan dalam model regresi linear, adakah korelasi antara periode $t$ dengan 
periode t-1 (sebelumnya) atau tidak. Model regresi yang baik adalah regresi yang bebas dari autokorelasi. Dalam penelitian ini uji autokerelasi yang digunakan adalah uji statistik run test. Suatu persamaaan regresi dikatakan terbebas autokorelasi jika nilai signifikan uji statistik run test diatas 0,05. Adapun hasil uji autokorelasi dengan menggunakan uji statistik run test adalah berikut ini:

Tabel 5. Hasil Uji Run Test

\begin{tabular}{|l|r|}
\hline & \multicolumn{1}{|c|}{$\begin{array}{c}\text { Unstandardized } \\
\text { Residual }\end{array}$} \\
\hline Test Value $^{\mathrm{a}}$ &, 00536 \\
Cases $<$ Test Value & 22 \\
Cases $>=$ Test Value & 23 \\
Total Cases & 45 \\
Number of Runs & 18 \\
Z & $-1,505$ \\
Asymp. Sig. (2-tailed) &, 132 \\
\hline
\end{tabular}

a. Median

Sumber: Data Diolah (2018)

Dilihat dari tabel 5 terlihat bahwa nilai signifikansi sebesar 0,132. Hal ini menunjukkan bahwa nilai tersebut atau sig $>0,05$ berarti dalam model regresi tidak terjadi autokorelasi dan layak untuk digunakan dalam penelitian.

\section{Regresi Linier Berganda}

Tabel 6. Ringkasan Hasil Pengujian Regresi Linier Berganda

\begin{tabular}{|c|c|c|c|c|}
\hline \multicolumn{5}{|c|}{ Dependent Variable: Profitabilitas (ROA) } \\
\hline Independent Variable & Coefficient & Std. Error & t-hitung & Sig. T \\
\hline $\mathrm{C}$ & $-0,175$ & 0,158 & $-1,107$ & 0,275 \\
\hline Financing to Deposit Ratio (FDR) & $-0,028$ & 0,046 & $-0,614$ & 0,543 \\
\hline Risiko Pemibiayaan (NPF) & $-1,013$ & 0,360 & $-2,813$ & 0,008 \\
\hline Kecukupan Modal (CAR) & 0,025 & 0,063 & 0,393 & 0,696 \\
\hline Dana Pihak Ketiga (DPK) & 0,007 & 0,005 & 1,521 & 0,137 \\
\hline Suku Bunga (BI rate) & $-0,145$ & 0,551 & $-0,264$ & 0,793 \\
\hline Inflasi & 0,395 & 0,248 & 1,595 & 0,119 \\
\hline \multicolumn{5}{|c|}{ Weighted Statistics } \\
\hline \multicolumn{5}{|c|}{$=3,252$} \\
\hline$=0,01$ & \multicolumn{4}{|c|}{$=0,011$} \\
\hline R Square & \multicolumn{4}{|c|}{$=0,339$} \\
\hline Adjusted R Square & \multicolumn{4}{|c|}{$=0,235$} \\
\hline
\end{tabular}

Sumber : Data Diolah (2018)

Namun dikarenakan variabel X1, X3, X4, X5, dan X6 tidak berpengaruh signifikan terhadap variabel $Y$, maka model regresi tersebut tidak bisa dijadikan model untuk memprediksi populasi dalam penelitian ini. Jika salah satu variabel $\mathrm{X}$ tidak berpengaruh signifikan, maka berapapun nilai $\mathrm{X}$ tersebut tidak akan mempengaruhi besar atau kecilnya nilai profitabilitas. Oleh karena itu, model regresi yang bisa dijadikan untuk memprediksi populasi dalam penelitian ini adalah:

$\mathrm{Y}=-0,175-1,013(\mathrm{X} 2)$

Berdasarkan hasil uji statistik di atas terlihat bahwa nilai $\mathrm{F}$ hitung sebesar 3 ,252. Untuk menghitung $F$ tabel maka digunakan rumus $F$ tabel $=(d k ; n-k-1)=F(6$; 
$38)=2,35$. Pada tabel di atas dapat diketahui bahwa $F$ hitung adalah sebesar 3,252 dah hasil $\mathrm{F}$ tabel adalah sebesar 2,35 (3,252 > 2,35) dengan signifikansi < 0,05 $(0,011$ $<0,05$ ). Maka, dapat disimpulkan bahwa Financing to Deposit Ratio (FDR), risiko pembiayaan, kecukupan modal, dana pihak ketiga, suku bunga, dan inflasi secara bersama-sama (simultan) berpengaruh terhadap profitabilitas pada Bank Umum Syariah (BUS). Nilai Adjusted $R$ Square mempunyai nilai sebesar 0,235. Hal ini berarti data hasil penelitian untuk variabel independen FDR, risiko pembiyaan, kecukupan modal, dana pihak ketiga, suku bunga, dan inflasi dalam menentukan profitabilitas dapat dijelaskan sebesar 23,50 \%. Sedangkan 76,50\% dijelaskan oleh faktor-faktor lain diluar variabel dalam penelitian ini.

Financing to Deposit Ratio (FDR) menunjukkan nilai t hitung negatif 0,614 dan nilai tersebut lebih kecil dari nilai t tabel $(0,614<2,02439)$ dengan signifikansi $>$ $0,025(0,543>0,025)$. Dari pengujian tersebut mengindikasikan bahwa FDR tidak berpengaruh signifikan terhadap profitabilitas. Maka, koefisien korelasi yang diuji signifikansinya tidak dapat diberlakukan ke populasi penelitian. Hasil tersebut mengindikasikan bahwa tinggi atau rendahnya FDR tidak berpengaruh terhadap profitabilitas pada Bank Umum Syariah. Tidak berpengaruhnya FDR bisa desebabkan karena tingginnya FDR akan menyebabkan likuiditas bank kurang baik sehingga bank kesulitan dalam memenuhi semua kewajiban yang harus segera dibayar. Salah satu kondisinya adalah apabila terjadi penarikan dana pihak ketiga secara tiba-tiba oleh nasabah, sehingga bank harus menggunakan dana antar bank (call money) untuk memenuhi kewajiban tersebut. Namun, nilai FDR rendah menunjukkan bahwa bank tersebut kurang melakukan fungsinya sebagai intermediasi, karena dana pihak ketiga yang dihimpun bank lebih besar dari pembiayaan yang disalurkan. Hal ini menyebabkan aset likuid bank tersebut tinggi. Seperti yang diungkapkan oleh Wahyudi et.al (2013) aset-aset likuid biasanya tidak memberikan tingkat bagi hasil yang tinggi. Penelitian ini konsisten dengan penelitian Mahmudah dan Harjanti (2016) dan Harianto (2017) yang tidak menemukan bukti bahwa FDR mempunyai pengaruh terhadap profitabilitas.

Risiko pembiayaan (NPF) memiliki nilai t hitung negatif sebesar 2,813 dan nilai tersebut lebih besar dari t tabel $(2,813>2,02439)$ dengan nilai signifikansi sebesar < 0,025 yaitu $(0,008<0,025)$. ini mengindikasikan bahwa risiko pembiayaan berpengaruh signifikan terhadap profitabilitas bank syariah. Maka, koefisien korelasi yang diuji signifikansinya dapat diberlakukan ke populasi penelitian. Koefisien regresi pada variabel risiko pembiayaan bernilai - 1,013. Tanda negatif pada koefisien regresi menunjukkkan hubungan tidak searah antara variabel independen dengan variabel dependennya. Hal ini berarti kenaikan risiko pembiayaan sebesar $1 \%$ akan menurunkan profitabilitas sebesar 1,013\%. Artinya, apabila risiko pembiayaan semakin tinggi akan menyebabkan penurunan terhadap nilai profitabilitas perbankan. Laporan Perkembangan Keuangan Syariah (2017) dijelaskan berdasarkan hasil evaluasi terhadap kemampuan membayar pembiayaan debitur, bank diwajibkan melakukan antisipasi terhadap kerugian atas tidak tertagihnya aset melalui pembentukan atau penyisihan dana Cadangan Kerugian Penurunan Nilai (CKPN). Apabila tingkat pembiayaan bermasalah meningkat, maka akan semakin banyaknya Cadangan Kerugian Penurunan Nilai (CKPN) yang dibentuk oleh bank. Oleh karena itu, beban penyisihan atas pencadangan tersebut juga akan bertambah besar. Hal ini menyebabkan menurunnya laba yang diperoleh oleh perbankan tersebut. Penelitian ini sejalan dengan penelitian yang dilakukan oleh Yusuf dan Mahriana (2016) dan 
Harianto (2017) yang menemukan bukti bahwa risiko pembiayaan mempunyai pengaruh terhadap profitabilitas perbankan.

Kecukupan modal memiliki nilai nilai t hitung sebesar positif 0,393 dan nilai tersebut lebih kecil dari t tabel $(0,393<2,02439)$ dengan nilai signifikansi $>0,025$ $(0,696>0,025)$. Dari pengujian tersebut mengindikasikan bahwa kecukupan modal tidak berpengaruh signifikan terhadap profitabilitas. Maka, koefisien korelasi yang diuji signifikansinya tidak dapat diberlakukan ke populasi penelitian. Tidak berpengaruhnya CAR bisa disebabkan oleh adanya upaya bank syariah untuk menjaga kecukupan modalnya yaitu sesuai ketentuan Peraturan Otoritas Jasa Keuangan Nomor 21/POJK/No.21/05/2014 tentang kewajiban penyediaan modal minimum bank umum syariah minimal 8\%, menyebabkan pihak perbankan akan hati-hati dalam menggunakan modalnya karena adanya kemungkinan risiko yang yang akan dihadapi. Penelitian ini konsisten dengan penelitian oleh Wibowo dan Syaichu (2013) yang menyatakan besar kecilnya CAR tidak mencerminkan keuntungan bank tersebut jika tidak dipergunakan secara efektif. Bank yang memiliki modal yang besar namun tidak menggunakan modalnya secara efektif untuk menghasilkan laba maka modal pun tidak akan berpengaruh terhadap profitabilitas bank. Hasil penelitian ini juga sejalan dengan Harianto (2017) yang tidak menemukan bukti bahwa kecukupan modal berpengaruh terhadap profitabilitas perbankan.

Dana Pihak Ketiga (DPK) memiliki nilai t hitung sebesar positif 1,521 dan nilai tersebut lebih kecil dari t tabel $(1,521<2,02439)$ dengan signifikansi $>0,025(0,137$ $>0,025$ ). Berarti Dana Pihak Ketiga (DPK) tidak berpengaruh signifikan terhadap profitabilitas. Maka, koefisien korelasi yang diuji signifikansinya tidak dapat diberlakukan ke populasi penelitian. Banyaknya jumlah dana pihak ketiga yang dihimpun belum tentu mempengaruhi profitabilitas. Hal ini dapat terjadi karena peningkatan dana pihak ketiga yang dihimpun tidak tersalurkan secara maksimal. Tidak maksimalnya penyaluran pembiayaan ini bisa disebabkan bank syariah sangat selektif dalam penyaluran pembiayaan yang akan diberikan. Sesuai dengan Peraturan Otoritas Jasa Keuangan Nomor 31/POJK/05/2014 tentang penyelenggaraan usaha pembiayaan syariah yang menjelaskan bahwa perusahaan syariah wajib melakukan mitigasi risiko pembiayaan syariah. Hal ini menyebabkan bank syariah, harus mempertimbangkan betul calon debitur yang akan dibiayai. Oleh karena itu berdasarkan Peraturan Otoritas Jasa Keuangan Nomor 16/P0JK.03/2014 dijelaskan bahwa bank wajib melaksanakan penanaman dan/atau penyediaan dana berdasarkan prinsip kehati-hatian dan prinsip syariah yang berdasarkan (1) Analisis kelayakan usaha dengan memperhatikan paling sedikit faktor 5C (character, capital, capacity, condition of economy dan collateral); dan/atau (2) Penilaian terhadap aspek prospek usaha, kinerja (performance), dan kemampuan membayar. Hasil penelitian ini konsisten dengan penelitian yang dilakukan oleh Mahmudah dan Harjanti (2016) yang tidak menemukan bukti bahwa dana pihak ketiga berpengaruh terhadap profitabilitas.

Suku bunga memiliki nilai t hitung untuk BI rate adalah negatif 0,264 dan nilai tersebut lebih kecil dari nilai $t$ tabel $(0,264<2,02439)$ dengan signifikansi $>0,025(0$, $793>0,025$ ). Berarti BI rate tidak berpengaruh signifikan terhadap profitabilitas. Maka, koefisien korelasi yang diuji signifikansinya tidak dapat diberlakukan ke populasi penelitian. Seperti yang dinyatakan oleh Wibowo dan Syaichu (2013) hal ini memperlihatkan nasabah bank syariah yang loyal dan tidak bisa dipengaruhi oleh 
tingkat suku bunga, yang mana nasabah bank syariah lebih mengutamakan prinsipprinsip syariah karena menilai bunga sebagai riba.

Inflasi memiliki nilai t hitung positif 1,595 dan nilai tersebut lebih kecli dari nilai $\mathrm{t}$ tabel $(1,595<2,02439)$ dengan signifikansi $>0,05(0,119>0,05)$. Hal ini menunjukkan inflasi tidak berpengaruh signifikan terhadap profitabilitas. Maka, koefisien korelasi yang diuji signifikansinya tidak dapat diberlakukan ke populasi penelitian. Berdasarkan hasil pengujian, mengindikasikan bahwa apabila terjadinya inflasi tidak menyebabkan berkurangnya penghimpunan dana pihak ketiga yang dilakukan oleh Bank Umum Syariah. Sehingga, inflasi tidak berpengaruh terhadap profitabilitas pada perbankan tersebut. Hal ini bisa disebabkan karena inflasi yang terjadi pada rentang waktu penelitian yaitu dari tahun 2013 sampai denan tahun 2017 merupakan jenis inflasi ringan. Dimana rata-rata inflasi tersebut kurang dari $10 \%$ per tahun. Sehingga tidak mampu mempengaruhi perekonomian dan perbankan secara menyeluruh. Penelitian ini konsisten dengan penelitian yang dilakukan oleh Wibowo dan Syaichu (2013) yang tidak menemukan bukti bahwa inflasi berpengaruh terhadap profitabilitas pada Bank Umum Syariah. Hal ini mengisyaratkan bahwa ada sedikit daya tahan bank syariah terhadap inflasi.

\section{KESIMPULAN DAN SARAN Kesimpulan}

Berdasarkan pengujian yang dilakukan pada Bank Umum Syariah dapat disimpulkan hasil penelitian sebagai berikut bahwa secara sendiri-sendiri risiko pembiayaan berpengaruh signifikan terhadap profitabilitas. Sedangkan Financing to Deposit Ratio (FDR), kecukupan modal, dana pihak, suku bunga dan inflasi tidak berpengaruh signifikan terhadap profitabilitas. Secara simultan Financing to Deposit Ratio (FDR), risiko pembiayaan, kecukupan modal, dana pihak ketiga, suku bunga dan inflasi berpengaruh terhadap profitabilitas pada Bank Umum Syariah.

\section{Keterbatasan Penelitian}

Penelitian ini memiliki keterbatasan-keterbatasan yang sekaligus dapat menjadi arahan bagi peneliti yang akan datang. Adapun keterbatasan dalam penelitian ini adalah sebagai berikut: (1) 1. Penelitian hanya dilakukan pada Bank Umum Syariah (BUS) yang terdaftar di Otoritas Jasa Keuangan (OJK) dan Bank Indonesia (BI) dengan periode penelitian selama 5 tahun yaitu 2013-2017, (2) Penggunaan proksi yang mewakili profitabilitas hanya dilihat dari Financing to Deposit Ratio (FDR), risiko pembiayaan, kecukupan modal, dana pihak ketiga, suku bunga dan inflasi.

\section{Saran}

Berdasarkan beberapa keterbatasan penelitian yang telah di ungkapkan, maka peneliti memberikan saran untuk penelitian selanjutnya yaitu: (1) Untuk penelitian selanjutnya bisa menambah rentang waktu penelitian yang lebih panjang sehingga bisa memperkuat hasil penelitian ini, (2) Penelitian selanjutnya bisa menambahkan variabel-variabel independen lain terkait dengan hal-hal yang mempengaruhi profitabilitas perbankan syariah mengingat $76,50 \%$ dari nilai variabel dependen dijelaskan oleh variabel lain diluar penelitian ini, (3) Untuk penelitian selanjutnya hendaknya memperluas penelitian mengenai profitabilitas pada bank syariah lain 
sehingga diketahui hal-hal yang mempengaruhi profitabilitas pada bank syariah di Indonesia dan bandingkan dengan perbankan konvensional.

\section{REFERENSI}

Bank Indonesia. (2013). Pengenalan Inflasi. Ditelusuri 11 Juli 2018. https://www.bi.go.id/id/moneter/inflasi/pengenalan/penjelasan/Contents/Default.asp $\mathrm{X}$

Bank Indonesia. (2013). Penjelasan BI Rate Sebagai Suku Bunga Acuan. Ditelusuri 11 Juli $2018 . \quad$ https://www.bi.go.id/id/moneter/birate/penjelasan/Contents/Default/aspx

Ghozali, Imam. (2009). Aplikasi Analisis Multivariate dengan Program SPSS. Semarang: UNDIP.

Harianto, Syawal. (2017). Rasio Keuangan dan Pengaruhnya Terhadap Profitabilitas pada Bank Pembiayaan Rakyat Syariah di Indonesia. Jurnal Bisnis dan Manajemen, 7 (1), 41-48

Kalengkongan, Glenda. (2013). Tingkat Suku Bunga dan Inflasi Pengaruhnya Terhadap Return On Asset (ROA) pada Industri Perbankan yang Go Public di Bursa Efek Indonesia. Jurnal EMBA,1(4), 737-747

Mahmudah, Nurul dan Ririh Sri Harjanti. (2016). Analisis Capital Adequacy Ratio, Financing To Deposit Ratio, Non Performing Financing, dan Dana Pihak Ketiga Terhadap Tingkat Profitabilitas Bank Umum Syariah Periode 2011-2013. Jurnal SENIT, 1(1), 134-143.

Muhamad. (2014). Manajemen Keuangan Syariah. Yogyakarta: UPP STIM YKPN.

Otoritas Jasa Keuangan. (2014). Peraturan Otoritas Jasa Keuangan Nomor 21/P0JK/No.21/05/2014 Tentang Kewajiban Penyediaan Modal Minimum Bank Umum. Ditelusuri $12 \quad$ September 2018. https://www.ojk.go.id/id/regulasi/otoritas-jasa-keuangan/peraturanojk/Documents/POJK21KewajibanPenyediaanModal

Otoritas Jasa Keuangan. (2016). UU No. 21 Tahun 2008 Tentang Perbankan Syariah. Ditelusuri 10 Juni 2018. https://www.ojk.go.id/id/kanal/perbankan/regulasi/ undang-undang/Pages/undang-undang-nomor-21-tahun-2008-tentang perbankan-syariah.aspx

Otoritas Jasa Keuangan. (2017). Laporan Perkembangan Keuangan Syariah (LPKS) Tahun 2017. Ditelusuri 28 Agustus 2018. https://www.ojk.go.id/id/berita-dankegiatan/publikasi/Pages/Laporan-Perkembangan-Perbankan-dan-KeuanganSyariah-2017.aspx

Sugiyono. (2017). Statistika untuk Penelitian. Bandung: Alfabeta 
Wahyudi, Imam., Dewi, Kartika Miranti., Rosmanita, Fenny., Prasetyo, Muhammad Budi., Putri, Niken Iwani Surya dan Banu Muhammad Haidir. (2013). Manajemen Risiko Bank Islam. Jakarta: Salemba Empat.

Wibowo, Edhi Satriyo dan Muhammad Syaichu. (2015). Analisis Pengaruh Suku Bunga, Inflasi, CAR, BOPO, NPF Terhadap Profitabilitas Bank Syariah. Jurnal Manajemen, 2(2), 1-10

Yusuf, Muhammad Yasir dan Wan Sri Mahriana. (2016). Faktor-faktor yang Mempengaruhi Tingkat Profitabilitas Bank Pembiayaan Rakyat Ryariah (BPRS) di Aceh. Jurnal Iqtashadia, 9(2), 246 - 275 